\title{
FOREIGN TRADE AND COMPARATIVE ADVANTAGES OF AGRARIAN SECTOR OF SERBIA AND NEIGHBOURING COUNTRIES
}

\author{
Dragica Božić ${ }^{1}$, Marija Nikolić2 \\ *Corresponding authorE-mail: mnikolic@agrif.bg.ac.rs
}

\begin{tabular}{l} 
A R T I C L E I N F O \\
Original Article \\
Received: 02 August 2019 \\
Accepted: 16 September 2019 \\
doi:10.5937/ekoPolj1903737B \\
UDC 339.5:631.1(497.11) \\
\hline
\end{tabular}

Keywords:

Revealed Comparative Advantages, agrarian sector, Serbia, neighbouring countries

JEL: F10, F14, Q17

\begin{abstract}
A B S T R A C T
Foreign trade of commodities of total economy of Serbia and countries in the region is characterized by a huge deficit. Small economies, such as these, are marked with significant trade openness that is result of their high import dependence. Agrarian sector has a high share in foreign trade of Serbia and neighbouring countries. Surplus in foreign trade exists only in Serbian agrarian sector, while the biggest trade deficit is recorded in Bosnia and Herzegovina, and the lowest level of foreign trade coverage $(9 \%)$ in agrarian sector of Montenegro. Comparative analysis of competitiveness was conducted on the basis of the revealed comparative advantage index. Comparative advantage in the exchange of agro-food products of Serbia with the world is achieved in ten commodity divisions, and the most significant are: cereals; vegetables and fruits; sugar and honey, and in recent years, tobacco and tobacco products. In countries of the region, there is significantly less number of divisions of agro-food products that are competitive on global market.
\end{abstract}

(C) 2019 EA. All rights reserved.

\section{Introduction}

Processes of integration and firm ties of national economies define the flows and characteristics of international trade. In addition to positive effects on economic growth and development, strengthening of competitiveness, rise of living standards and reduction of poverty, a high level of openness towards foreign trade can also cause certain negative effects due to greater vulnerability to external events.

Serbia and neighbouring countries analyzed in the paper (Bosnia and Herzegovina, Montenegro and North Macedonia) are in the process of EU integration, and some of them are on the path to meet conditions for admission to the WTO, which implies the

1 Dragica Božić, Full Professor, University of Belgrade, Faculty of Agriculture, Nemanjina 6, 11080 Belgrade, Serbia, bozdrag@agrif.bg.ac.rs , ORCID ID: 0000-0001-8376-5241

2 Marija Nikolić, Assistant professor, University of Belgrade, Faculty of Agriculture, Nemanjina 6, 11080 Belgrade, Serbia, mnikolic@agrif.bg.ac.rs , ORCID IS: 0000-00028691-7113 
implementation of EU regulations and WTO rules, including significant adjustments in foreign trade policy and market liberalization. These adjustments are particularly complex in the agrarian sector, which must be aligned with constantly reforming EU Common Agricultural Policy, as well as the rules of the WTO Agriculture Agreement, since it is the only sector with severe restrictions imposed by WTO.

The process of trade liberalization for the South East European countries begun in 2000's and resulted in signing the New CEFTA Agreement in 2006 and establishment of the free trade area of Western Balkan countries. Main objective of the agreement is to promote trade, and according to a joint declaration, all parties are bound to comply with WTO rules. As an exceptionally sensitive sector, given possible threats it faces, the agrarian sector is still relatively important in national economies of these countries, measured by the share in GDP, employment, or foreign trade. Therefore, it is more and more important to examine the competitiveness of this sector, in conditions of increasing openness towards foreign trade.

The aim of the paper is to compare basic characteristics of foreign trade of commodities, agrarian sector and comparative advantages of certain groups (divisions) of agro-food products in Serbia and selected countries in the region in the period after the economic crisis (2008) until 2017.

The starting hypotheses in the paper are that the agrarian sector of Serbia has a greater importance for levelling the balance of trade and it also has comparative advantages on global market in comparison with the selected countries in the region.

\section{Theoretical framework of the research}

The study of the effects of integrative processes in global economy on the characteristics of international trade is widespread in economic theory. Economic structure, level of economic and technical-technological development and achieved level of productivity and competitiveness defines how much a country will be successful in international trade. The trade openness index is used as a basis indicator of involvement in global economic flows. It is calculated as a participation of total foreign trade (imports and exports) in gross domestic product (GDP).

The concept of country's openness is most often analyzed through an examination of impact on economic growth and development. In an analysis of openness it is important to distinguish imports and exports flows, and to determine the degree of dependence on exports (export ratio), and dependence on imports (import ratio). Numerous studies indicate that there is a positive and strong link between exports and economic growth and development (López \& Dawson, 2010; Haddad at al., 2011; Tešić, 2013; Boljanović, 2013; Ali et al., 2017; Gözgör \& Can, 2017; Sayef, 2017). Some authors, however, question the existence of a positive link between openness and growth, due to the difference in understanding the concept of openness (Baldwin, 2003). It is particularly emphasized that highly open economies (like small and transitional countries) are more exposed to external shocks. The Western Balkan countries are significantly integrated 
into the global economic flows, although not highly developed and with exports below potential. The economic crisis in these countries manifested in reducing exports to traditional export markets, and decline in FDI (foreign direct investments).

Tešić (2013) states that key benefit of a country's external orientation is achieving the competitiveness at a global level, but that it is extremely important for small economies to distinguish foreign trade flows on imports and exports. The competitiveness of small transition economies is reduced to the original concept of competitiveness, which looks at the exports performance of a county, where greater export participation means greater competitiveness.

There is no unique definition of competitiveness in economic theory. One of the definitions widely accepted in economic literature includes not only the product market, but also the factors of production, and states: "Competitiveness is an indicator of the ability to supply goods and services in the location and form and at the time they are sought by buyers, at prices that are as good as or better than those of other potential suppliers, while earning at least the opportunity cost of returns on resources employed" (Freebairn, 1987: 79).

Micro competitiveness refers to individual enterprise or groups of enterprises and represents their relative advantage over other (foreign) enterprises. Macro level (macro competitiveness) refers to the competitiveness of national economies as a whole in relation to other economies. National competitiveness arises from the competitiveness of companies included in the economy, and therefore it is result of micro competitiveness, which is one of Michael Porter's starting points (Porter, 1990). "In the past, countries' development was based on comparative advantages, for example low labour cost and natural resources. However, in the modern business environment, international competitiveness stems from advanced factor conditions based on knowledge and "modern" infrastructure, high technology and innovation" (Šegota et al., 2017: 127).

The increase in popularity of macroeconomic concept followed after the World Economic Forum (WEF) experts developed the aggregated Global Competitiveness Index-GCI, based on Porter's research. GCI is published in annual publication "The Global Competitiveness Report" and serves to rank and compare countries according to the achieved level of competitiveness based on various microeconomic and macroeconomic factors. The competitiveness represented by GCI is defined as a set of institutions, policies and factors that determine the degree of productivity of an economy (WEF, 2018).

Since competitiveness is a result of many factors, measuring competitiveness and identifying key indicators is accompanied by significant difficulties. Calculation of competitiveness indicators can be applied for different levels of commodity aggregation: economy, sector, enterprise and individual product (or group of products), as well as for different territories (region, state, and world) (Frohberg and Hartmann, 1997).

In an effort to overcome numerous difficulties related to the measurement of competitiveness and comparative advantages of individual sectors and their comparison 
between countries, Balassa (1965) started from actual trade data and based on them defined the concept of the Revealed Comparative Advantage Index (RCA) of a country. This index was first applied by Liesner (1958), but it was popularized by Balassa. In practice, this is a commonly accepted method to analyse trade data known as Balassa Index and it is used to identify advantages and weaknesses of a country in export. If the share of export of a commodity group of a country in global export is higher than the share of that commodity group in the global exports, then that country has comparative advantages in export of this commodity group. This means that the state can produce these products at a lower price than other countries, and that most of its own resources should be devoted to the production of these goods. The Balassa index tries to identify whether a country (sector) has "revealed" comparative advantages rather than to determine the underlying sources of comparative advantage (Božić and Nikolić, 2013-a).

Balassa index, or the RCA definition, has been often changed, and today there is a large number of modified indicators (Fertö and Hubbard, 2002; Bojnec and Fertö, 2007; Božić and Nikolić, 2013-a). Import restrictions, export subsidies and other protectionist policy measures may affect and create a "distortion" of calculated RCA index. This also means that one can make wrong conclusions about the level of open comparative advantage of a sector or a country, based only on the RCA index.

All Western Balkan countries export less of their potential and have a large foreign trade deficit. The structure of their exports is dominated by primary products and raw materials, among which agro-food products play an important role. Research shows that the opportunities of Serbian economy and countries in the region for increasing exports are underutilized. The main reason is insufficient competitiveness (Jefferson Institute, 2003; Jaćimović et al., 2013; Boljanović, 2013; Božić and Nikolić, 2017).

\section{Method of work and data sources}

To determine the position and performance of a country on global market in the exchange with other countries, the following indicators were used:

$\sim$ Trade Openness Index (country dependence on foreign trade) measured as the ratio of country's total trade to the gross domestic product (GDP);

$\sim$ Export ratio (country dependence on exports) is the value of a country's export as a percentage of its GDP;

$\sim$ Import ratio (country dependence on imports) is the value of a country's import as a percentage of its GDP;

$\sim$ Foreign trade coverage ratio (TCR) shows how many percent of export is covered by import and represent the ratio between the value of country's exports (X) and imports (M);

$\sim$ Revealed Comparative Advantage (RCA) was used to determine the 
comparative advantages of agrarian sector of Serbia and neighbouring countries. In addition to original Balassa Index, modified $\mathrm{RCA}_{2}$ and $\mathrm{RCA}_{3}$ indicators were calculated.

The original Balassa index was calculated according to the formula (Balassa, 1965):

$$
R C A_{1}=\frac{\frac{X_{i j}}{X_{i t}}}{\frac{X_{n j}}{X_{n t}}}=\frac{\frac{X_{i t}}{X_{n j}}}{\frac{X_{i t}}{X_{n t}}}
$$

where $X$ represents exports, $i$ is a country, $j$ is a commodity (or an industry), $t$ is a set of commodities (or industries) and $n$ is a set of countries.

This index measures country's export share in a given commodity to global market relative to its share of total exports in global exports of all remaining commodities. If the share of exports of a single commodity of a country in its total exports is higher than the share of exports of that commodity in all (remaining) countries in global exports, (beside that commodity), a comparative advantage is "revealed" $\left(\mathrm{RCA}_{1}>1\right) .{ }^{3}$ If $\mathrm{RCA}_{1}$ is less than unity (one), country has a comparative disadvantage in that commodity / industry.

The RCA 1 doesn't include country's imports into account, and therefore it was exposed to significant criticism from numerous authors (Vollrath, 1991; Bojnec, 2001; Fertö and Hubbard, 2002; Utkulu and Seymen, 2004). So, an alternative RCA index (Equation 2 ) is computed in order to make reference only to "own" country trade performance:

$$
R C A_{2}=\frac{X_{i j}-M_{i j}}{X_{i j}+M_{i j}}
$$

where $X$ represents exports, $M$ is import, $i$ is a country and $j$ a commodity (or industry).

The $\mathrm{RCA}_{2}$ indicator is a ratio of trade balance of a commodity of a particular country and total foreign trade of that country with the world. The index ratio ranges from - 1 to +1 . The positive value of $\mathrm{RCA}_{2}$ for a particular commodity indicates that the country has comparative advantages (surplus) in the trade of this commodity. Regarding $\mathrm{RCA}_{2}$, there exist ambiguities around zero values.

Additional form of RCA index has been used in order to determine the comparative advantages of individual commodity of agrarian sector of Serbia and neighbouring countries. It is calculated according to the following formula (Balassa, 1965; Utkulu and Seymen, 2004; Božić and Nikolić, 2013-a):

3 When calculating this indicator, it is important to note that the commodity and the country in question are excluded from total exports. This is especially important if this country has a major share on global market and if this product is significantly represented in total export. 


$$
R C A_{3}=\frac{\frac{X_{i j}}{X_{i t}}}{\frac{M_{i j}}{M_{i t}}}=\frac{\frac{X_{i t}}{M_{i j}}}{\frac{X_{i t}}{M_{i t}}}(3)
$$

where $X$ represents exports, $M$ is import, $i$ is a country, $j$ is a commodity (section) and $t$ is a set of commodities (or industries).

The $\mathrm{RCA}_{3}$ index of comparative advantage measures the share of export of a commodity (industry) in total country's exports to a particular market relative to the share of imports of that commodity (industry) in total country's imports from that market. The value of $\mathrm{RCA}_{3}$ greater than 1 indicates that the commodity (industry) has comparative advantages on a given market comparing to other sectors of national economy.

The main source of data for research in this paper was the United Nations Conference on Trade and Development (UNCTAD). The Standard International Trade Classification SITC-rev.4 was used. According to this classification agrarian (agricultural and food products) includes section 0-Food and live animals (divisions: 01-09); Sector 1-Beverages and tobacco (divisions: 11 and 12); Sector 2-Crude materials, inedible, except fuels (divisions: 21, 22 and 29); and Sector 4-Animal and vegetable oils, fats and waxes (divisions: 41, 42 and 43).

\section{Foreign trade of total economy of Serbia and countries in the region}

The Western Balkan countries have begun integration processes that require further harmonization and achievement of European standards. The foreign trade policy of these countries in the period after 2000 has been significantly liberalized, and through numerous free trade agreements begun their gradual integration into international trade flows (Božić and Nikolić, 2017). Data on value of total exports and imports, as well as the permanent trade deficit, indicate a low level of competitiveness of Serbian and economies of countries in the region (Table 1).

According to the Global Competitiveness Report of the World Economic Forum for 2018, Serbian economy made progress ranking $65^{\text {th }}$ among 140 countries (while in the previous year it was at the $70^{\text {th }}$ position). The economy of $\mathrm{BiH}\left(91^{\text {st }}\right.$ place) has the smallest competitive advantages related to countries in the region, while North Macedonia is positioned at 84 , and Montenegro is on $71^{\text {st }}$ place (WEF, 2018). 
Table 1. Indicators of foreign trade of total economy of Serbia and selected countries in the region in period 2009-2017

\begin{tabular}{|c|c|c|c|c|}
\hline Indicator & $\begin{array}{c}\text { Ø (2009- } \\
2011)\end{array}$ & $\begin{array}{c}\text { Ø (2012- } \\
2014)\end{array}$ & 2015 & 2017 \\
\hline \multicolumn{5}{|c|}{ Serbia } \\
\hline Export (mil. US \$) & 9,973 & 13,561 & 13,379 & 16,959 \\
\hline Import (mil. US \$) & 17,548 & 20,028 & 18,210 & 22,146 \\
\hline Balance of trade (mil. US \$) & $-7,575$ & $-6,467$ & $-4,831$ & $-5,187$ \\
\hline Export ratio & 22.0 & 29.2 & 28.5 & 34.2 \\
\hline Import ratio & 38.6 & 43.1 & 38.7 & 44.7 \\
\hline Trade Openness Index & 60.6 & 72.3 & 67.2 & 78.9 \\
\hline Foreign trade coverage ratio $(\%)$ & 56.8 & 67.7 & 73.5 & 76.6 \\
\hline $\mathrm{RCA}_{2}$ & $\begin{array}{r}-0.28 \\
\end{array}$ & -0.19 & -0.15 & -0.13 \\
\hline \multicolumn{5}{|c|}{ Bosnia and Herzegovina } \\
\hline Export (mil. US \$) & $\begin{array}{r}4,869 \\
\end{array}$ & 5,580 & 5,099 & 6,367 \\
\hline Import (mil. US \$) & 9,546 & 10,435 & 8,994 & 10,444 \\
\hline Balance of trade (mil. US \$) & $-4,677$ & $-4,855$ & $-3,895$ & $-4,078$ \\
\hline Export ratio & 28.3 & 31.8 & 27.8 & 32.6 \\
\hline Import ratio & 55.6 & 59.5 & 49.0 & 53.6 \\
\hline Trade Openness Index & 83.9 & 91.3 & 76.8 & 86.2 \\
\hline Foreign trade coverage ratio $(\%)$ & 51.0 & 53.5 & 56.7 & 61.0 \\
\hline $\mathrm{RCA}_{2}$ & -0.32 & -0.30 & -0.28 & -0.24 \\
\hline \multicolumn{5}{|c|}{ North Macedonia } \\
\hline Export (mil. US\$) & $\begin{array}{r}3,507 \\
\end{array}$ & 4,426 & 4,490 & 5,670 \\
\hline Import (mil. US\$) & 5,848 & 6,814 & 6,400 & 7,719 \\
\hline Balance of trade (mil. US\$) & $-2,341$ & $-2,388$ & $-1,910$ & $-2,049$ \\
\hline Export ratio & 37.4 & 44.8 & 42.3 & 51.8 \\
\hline Import ratio & 62.4 & 68.9 & 60.3 & 70.5 \\
\hline Trade Openness Index & 99.8 & 113.7 & 102.6 & 122.3 \\
\hline Foreign trade coverage ratio $(\%)$ & 60.0 & 65.0 & 70.2 & 73.5 \\
\hline $\mathrm{RCA}_{2}$ & -0.25 & -0.21 & -0.18 & -0.15 \\
\hline \multicolumn{5}{|c|}{ Montenegro } \\
\hline Export (mil. US\$) & 484 & 468 & 353 & 421 \\
\hline Import (mil.US\$) & 2,346 & 2,351 & 2,050 & 2,611 \\
\hline Balance of Trade (mil. US\$) & $-1,862$ & $-1,883$ & $-1,697$ & $-2,190$ \\
\hline Export ratio & 11.7 & 10.9 & 7.8 & 8.6 \\
\hline Import ratio & 56.6 & 54.9 & 45.3 & 53.5 \\
\hline Trade Openness Index & 68.3 & 65.9 & 53.1 & 62.1 \\
\hline Foreign trade coverage ratio $(\%)$ & 20.6 & 19.9 & 17.2 & 16.1 \\
\hline $\mathrm{RCA}_{2}$ & -0.66 & -0.67 & -0.71 & -0.72 \\
\hline
\end{tabular}

Source: Authors' calculations based on UNCTADStat http://unctadstat.unctad.org/EN/

Trade Openness Index of economies of Serbia and neighbouring countries is large, and exceeds 60\% (Table 1). The Export ratio of all analyzed countries increased. The share of Serbian exports to GDP ranged from 22\% to 34\%, similar like in Bosnia and Herzegovina. However, this indicator is significantly higher for North Macedonia and in 2017 it was 52\%, while it is the lowest in Montenegro where the exports share 
accounts for only about 9\% of GDP. Although growth of imports is lower than growth of exports in all these countries (except in Montenegro), they all have high import ratio, which in Serbia is 45\%, and in Bosnia and Herzegovina and Montenegro 53\%, while the highest is in North Macedonia (about 70\%). These indicators confirm results of previous research stated that high openness of small, transitional economies arises primarily from their high import dependence.

Foreign trade coverage ratio in Serbia increased from about $57 \%$ to $77 \%$ and it is the highest in the region. In North Macedonia this indicator is about 73\%, and in Bosnia and Herzegovina $61 \%$. The lowest foreign trade coverage ratio is present in Montenegro (in 2017 it is $16 \%$ ), and it is continuously decreasing.

Unsatisfactory competitiveness of economy of Serbia and neighbouring countries is confirmed by calculated index of the revealed comparative advantage $\left(\mathrm{RCA}_{2}\right)$. For all countries and in the entire analysed period, $\mathrm{RCA}_{2}$ has values less than zero, which confirms that there are no revealed comparative advantages of analyzed economies in foreign trade with the world.

\section{Foreign trade and significance of agrarian sector in Serbia and neighbouring countries}

Agro-food products are traditionally significant for the overall economic development of the Republic of Serbia, including the contribution to foreign trade, especially levelling the balance of trade (Božić and Nikolić, 2016). Agrarian sector has a special contribution in countries in the region. Involvement in international integration processes and increasing openness of economies of these countries has led to significant changes in the scope, structure, territorial orientation and regime of foreign trade of agricultural and food products (Božić and Nikolić, 2013-b).

The value of exports of agro-food products is the highest in Serbia and in 2017 it exceeds USD 3 billion, i.e. it increased by $40 \%$ compared to the base three-year period (2009-2011). The value of Serbian agrarian exports is about five times higher in relation to exports of Bosnia and Herzegovina, and Macedonia, while it is about 57 times higher than the value of agrarian exports of Montenegro (Table 2).

The value of Serbian imports of agro-food products in the observed period also increased (by around 50\%) and reached almost USD 1.7 billion, which is $9 \%$ less than imports of $\mathrm{BiH}$, about two times higher than agrarian imports of Macedonia and approximately three times the value of agrarian imports of Montenegro.

Among the selected Western Balkan countries only Serbia has positive foreign trade balance in the exchange of agrarian products, which is constantly growing. The largest deficit in the foreign trade of agrarian sector is recorded in Bosnia and Herzegovina (about 1.3 billion USD), while in Montenegro it is about 0.5 billion USD, and in Macedonia about 250 million USD.

The foreign trade coverage ratio of agro-food products in the observed period exceeds 
$100 \%$ only in Serbia, which points to the competitiveness of agrarian sector and separates it from other sectors of Serbian economy. Increased opening of the country and trade liberalization caused certain oscillations and a slight decrease in the foreign trade coverage ratio compared to the first three-year period (2009-2011), but it remains high and exceeds $180 \%$. The foreign trade coverage ratio of agrarian sector is the lowest in Montenegro (only 9.1\% in 2017), in Bosnia and Herzegovina was around $30 \%$, despite the growth, and in Macedonia about $70 \%$.

Table 2. Comparative overview of foreign trade of agro-food products (AFP) and its participation in total exchange of Serbia and neighbouring countries

\begin{tabular}{|c|c|c|c|c|}
\hline Indicator & $\begin{array}{c}\text { O (2009- } \\
2011)\end{array}$ & $\begin{array}{c}\varnothing(2012- \\
2014)\end{array}$ & 2015 & 2017 \\
\hline \multicolumn{5}{|c|}{ Serbia } \\
\hline AFP export (mil. US\$) & 2,222 & 2,860 & 2,869 & 3,140 \\
\hline AFP import (mil. US \$) & 1,122 & 1,585 & 1,580 & 1,686 \\
\hline Balance of trade of AFP (mil. US \$) & 1,099 & 1,275 & 1,289 & 1,453 \\
\hline Foreign trade coverage ratio of AFP (\%) & 198.0 & 180.5 & 181.6 & 186.2 \\
\hline AFP exports in total exports (\%) & 22.3 & 21.1 & 21.4 & 18.5 \\
\hline AFP imports in total imports $(\%)$ & 6.4 & 7.9 & 8.7 & 7.6 \\
\hline $\mathrm{RCA}_{2}$ & 0.33 & 0.29 & 0.29 & 0.30 \\
\hline \multicolumn{5}{|c|}{ Bosnia and Herzegovina } \\
\hline AFP export (mil. US\$) & 432 & 488 & 554 & 562 \\
\hline AFP import (mil. US \$) & 1,826 & 1,907 & 1,704 & 1,840 \\
\hline Balance of trade of AFP (mil. US \$) & $-1,395$ & $-1,419$ & $-1,150$ & $-1,278$ \\
\hline Foreign trade coverage ratio of AFP (\%) & 23.6 & 25.6 & 32.5 & 30.5 \\
\hline AFP exports in total exports (\%) & 8.9 & 8.7 & 10.9 & 8.8 \\
\hline AFP imports in total imports $(\%)$ & 19.2 & 18.3 & 19.0 & 17.5 \\
\hline $\mathrm{RCA}_{2}$ & -0.62 & -0.59 & -0.51 & -0.53 \\
\hline \multicolumn{5}{|c|}{ North Macedonia } \\
\hline AFP export (mil.US\$) & 568 & 642 & 538 & 604 \\
\hline AFP import (mil. US \$) & 748 & 861 & 770 & 852 \\
\hline Balance of trade of AFP (mil. US \$) & -180 & -219 & -232 & -248 \\
\hline Foreign trade coverage ratio of AFP (\%) & 76.0 & 74.5 & 69.8 & 70.9 \\
\hline AFP exports in total exports (\%) & 16.2 & 14.5 & 12.0 & 10.7 \\
\hline AFP imports in total imports (\%) & 12.8 & 12.6 & 12.0 & 11.0 \\
\hline $\mathrm{RCA}_{2}$ & -0.14 & -0.15 & -0.18 & -0.17 \\
\hline \multicolumn{5}{|c|}{ Montenegro } \\
\hline AFP export (mil. US\$) & 69 & 97 & 64 & 55 \\
\hline AFP import (mil. US \$) & 567 & 605 & 521 & 600 \\
\hline Balance of trade of AFP (mil. US \$) & -499 & -508 & -457 & -545 \\
\hline Foreign trade coverage ratio of AFP (\%) & 12.1 & 16.1 & 12.3 & 9.1 \\
\hline AFP exports in total exports (\%) & 14.2 & 20.8 & 18.1 & 13.0 \\
\hline AFP imports in total imports $(\%)$ & 24.2 & 25.7 & 25.4 & 23.0 \\
\hline $\mathrm{RCA}_{2}$ & -0.78 & -0.72 & -0.78 & -0.83 \\
\hline
\end{tabular}

Source: Authors' calculations based on UNCTADStat 
The observed tendencies in foreign trade exchange of total economy, as well as the exchange of agro-food products of Serbia and countries in the region caused significant differences in terms of participation of agrarian sector in total exports. This share is the highest in Serbia (about 20\%), which may be the result of use of available resources for development of agriculture and slow development of other sectors. The lowest share of agro-food sector in total exports is constantly present in Bosnia and Herzegovina (around $9 \%$ ). The share of agrarian sector in total exports over the last decade is decreasing in Macedonia - about $16 \%$ in the first three year period reduces to about $11 \%$ in 2017 ; and in Montenegro, where it significantly oscillated and in 2017 it reduced to $13 \%$.

The share of agro-food products in total imports of Serbia and countries in the region is mainly decreasing in the observed period. In 2017 the lowest share of agrarian products in total imports of around 8\% existed in Serbia, while in Macedonia it amounted 11\%, Bosnia and Herzegovina 18\% and in Montenegro 23\%.

Positive $\mathrm{RCA}_{2}$ index values indicates that the revealed comparative advantages in the foreign trade exchange with the world has only agrarian sector of Serbia, i.e. it is more competitive in relation to this sector in selected countries in the region.

\section{Comparative advantages of agrarian sector of Serbia and neighbouring countries}

The analysis of the revealed comparative advantages carried out for individual divisions within the agrarian sector in 2009, 2012, 2015 and 2017 for Serbia and neighbouring countries indicates the existence of significant differences in terms of the level of competitiveness.

The RCA index is used in order to determine the position of divisions of agro-food products of Serbia and neighbouring countries on global market. This index shows which commodity divisions contribute most to the export, or to the reduction of foreign trade deficit of individual economies. Value of $\mathrm{RCA}_{1}$ higher than unity (one) indicates that a commodity division has comparative advantages in the exchange with the world. There are ten such divisions in Serbia, in all years of observation: 00Live animals; 02-Dairy products and birds' eggs; 04-Cereals and cereal preparations; 05-Vegetables and fruit; 06-Sugars, sugar preparations and honey; 08-Feeding stuff for animals; 09-Miscellaneous edible products and preparations; 11-Beverages; 12-Tobacco and tobacco manufactures and 42-Fixed vegetable fats and oils, crude, rafined or fractionated (Table 3).

The highest values of RCA in Serbia in the first year of analysis had division 06-Sugars, sugar preparations and honey, due to preferential export status to the EU market in 2000. In following years the comparative advantage of this division is declining as the result of sugar sector reform in the EU, the abolition of production quotas, and strong competition from the world's major sugar beet producers. High level of comparative advantage had division 04-Cereals and cereal preparations and 05-Vegetables and fruit, which in the following years became more competitive. Cereals, especially corn and wheat, are significant export products of Serbia. However, in recent years, the highest 
level of competitiveness, measured by the $\mathrm{RCA}_{1}$ index, has division 12-Tobacco and tobacco manufactures, followed by 04-Cereals and cereal preparations and 05-Vegetables and fruit.

Divisions with the lowest $\mathrm{RCA}_{1}$ index values in Serbia during the entire period of analysis, which indicating that they are uncompetitive on global market are 01- Meat and meat preparations and 03-Fish, crustaceans and molluscs. The number of livestock in Serbia is continuously decreasing which has reflected on reduction of meat production and import growth.

In Bosnia and Herzegovina, the comparative advantages in all years of analysis have a smaller number of agrarian divisions compared to Serbia, a total of five, namely: 02-Dairy products and birds' eggs; 05-Vegetables and fruit; 06-Sugars, sugar preparations and honey; 21-Hides, skins and furskins, raw and 42-Fixed vegetable fats and oils (Table 3). Nine divisions in $\mathrm{BiH}$ in all years have $\mathrm{RCA}_{1}$ values less than 1 , which indicate their non-competitiveness on global market.

Table 3. The revealed comparative advantage indexes-RCA $\mathrm{A}_{1}$ of individual SITC divisions of agrarian sector of Serbia and Bosnia and Herzegovina on global market

\begin{tabular}{|l|r|r|r|r|r|r|r|r|}
\hline & \multicolumn{4}{|c|}{ Serbia } & \multicolumn{3}{|c|}{ Bosnia and Herzegovina } \\
\cline { 2 - 10 } & $\mathbf{2 0 0 9}$ & $\mathbf{2 0 1 2}$ & $\mathbf{2 0 1 5}$ & $\mathbf{2 0 1 7}$ & $\mathbf{2 0 0 9}$ & $\mathbf{2 0 1 2}$ & $\mathbf{2 0 1 5}$ & $\mathbf{2 0 1 7}$ \\
\hline 00-Live animals & 4.76 & 4.35 & 3.49 & 2.42 & 0.26 & 0.67 & 0.36 & 0.41 \\
\hline 01- Meat and preparations & 0.92 & 0.76 & 0.89 & 0.80 & 0.89 & 0.88 & 2.17 & 0.69 \\
\hline 02- Dairy products \& eggs & 1.54 & 1.65 & 1.38 & 1.08 & 2.45 & 2.57 & 1.24 & 1.23 \\
\hline 03- Fish and preparations & 0.09 & 0.05 & 0.06 & 0.12 & 0.44 & 0.28 & 0.22 & 0.31 \\
\hline 04- Cereals \& preparations & 5.86 & 7.79 & 4.89 & 3.55 & 0.93 & 0.84 & 1.21 & 1.57 \\
\hline 05- Vegetables \& fruit & 4.05 & 4.18 & 3.97 & 3.48 & 1.23 & 0.90 & 1.70 & 1.23 \\
\hline 06- Sugars \& honey & 6.53 & 5.85 & 3.22 & 2.38 & 1.86 & 3.07 & 1.45 & 1.53 \\
\hline 07- Coffee, tea, cocoa & 1.73 & 1.28 & 0.98 & 0.88 & 0.68 & 0.61 & 0.62 & 0.49 \\
\hline 08-Feeding stuff for anim. & 1.70 & 2.85 & 1.79 & 2.43 & 0.44 & 0.59 & 0.53 & 0.44 \\
\hline 09-Miscell. edible products & 2.36 & 2.39 & 1.97 & 1.77 & 0.81 & 0.64 & 0.55 & 0.40 \\
\hline 11-Beverages & 3.86 & 3.56 & 2.40 & 2.00 & 1.07 & 1.00 & 0.81 & 1.00 \\
\hline 12-Tobbaco\&manufactures & 2.24 & 2.67 & 7.42 & 6.64 & 1.32 & 0.92 & 0.66 & 0.50 \\
\hline 21-Hides, skins, furskins & 3.06 & 4.61 & 3.56 & 0.57 & 13.71 & 18.73 & 14.04 & 10.38 \\
\hline 22-Oil-seeds \& ol. fruits & 0.72 & 1.20 & 2.00 & 1.76 & 0.06 & 0.07 & 0.05 & 0.26 \\
\hline 29-Crude an. \& veg. mat. & 1.04 & 0.91 & 0.74 & 0.62 & 0.33 & 0.44 & 0.54 & 0.19 \\
\hline 41-Animal oils \& fats & 0.59 & 0.79 & 0.61 & 1.12 & 0.00 & 0.01 & 0.00 & 0.00 \\
\hline 42-Fixed veg. fats \& oils & 3.22 & 3.44 & 2.55 & 2.19 & 1.97 & 1.97 & 3.35 & 3.35 \\
\hline $\begin{array}{l}\text { 43-Anim. or veg. fats \& oils, } \\
\text { pr. }\end{array}$ & 1.32 & 1.26 & 0.81 & 0.64 & 0.18 & 0.22 & 0.20 & 0.24 \\
\hline
\end{tabular}

Source: Authors' calculations based on UNCTADStat

Five commodity divisions from North Macedonia have comparative advantages in exports on global market: 04-Cereals and cereal preparations; 05-Vegetables and fruit; 11-Beverages; 12-Tobacco and tobacco manufactures and 21-Hides, skins and furskins, raw (Table 4). The highest value of $\mathrm{RCA}_{1}$ has division 12-Tobacco 
and tobacco manufactures, followed by division 05-Vegetables and fruit and 11-Beverages. A total of seven commodity divisions of agro-food products from North Macedonia have $\mathrm{RCA}_{1}$ index values less than one in all analyzed years, i.e. they are not competitive on global market.

Table 4. The revealed comparative advantage indexes-RCA $A_{1}$ of individual SITC divisions of agrarian sector of Macedonia and Montenegro on global market

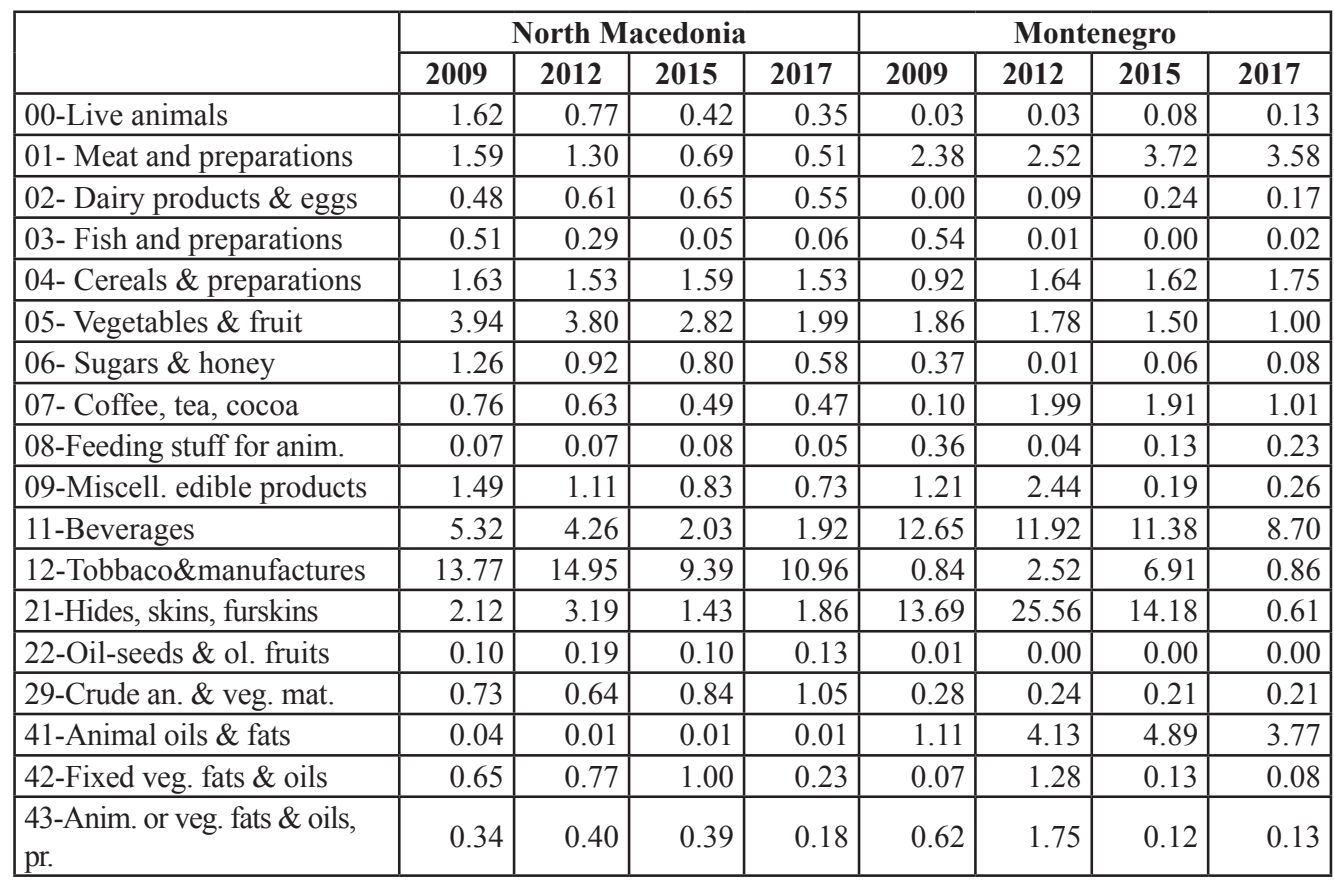

Source: Authors' calculations based on UNCTADStat

Only four divisions of Montenegro's agrarian sector have comparative advantages in exports to global market $\left(\mathrm{RCA}_{1}>1\right)$, namely: 01-Meat and meat preparations; 05-Vegetables and fruit; 11-Beverages and 41-Animal oil and fats. The highest index values are characteristic for division 11-Beverages, which confirm its greatest competitiveness on global market. Division 41-Animal oil and fats has comparative advantages only in Montenegro. Nine divisions of agro-food products of Montenegro in all observed years have no competitive advantage on global market (including live animals, dairy products and eggs, fish and products, sugar, and fodder).

All Serbian agro-food divisions have comparative advantages in all years of analysis, measured by $\mathrm{RCA}_{3}$ index, except 03-Fish, crustaceans and molluscs and 41-Animal oil and fats (Table 5). In addition to these two divisions of agro-food products, comparative advantages, in some years of analysis, did not have divisions 07-Coffee, tea, cocoa, spices, and manufactures, 22-Oil-seeds and oleaginous fruits and 29-Crude animal and vegetable materials. Production of these products is limited or completely disabled in domestic conditions, so they are imported. 
Comparative advantages in Bosnia and Herzegovina generate only division 21-Hides, skins and furskins, raw and 42-Fixed vegetable fats and oils.

Special significance in national economy of North Macedonia and comparative advantages have divisions: 00-Live animals; 04-Cereals and cereal preparations (except in 2009); 05-Vegetables and fruit; 11-Beverages; 12-Tobacco and tobacco manufactures; and 21-Hides, skins and furskins, raw.

Table 5. The revealed comparative advantage indexes- $\mathrm{RCA}_{3}$ of individual SITC divisions of agrarian sector of Serbia and Bosnia and Herzegovina on global market

\begin{tabular}{|l|r|r|r|r|r|r|r|r|}
\hline & \multicolumn{4}{|c|}{ Serbia } & \multicolumn{3}{|c|}{ Bosnia and Herzegovina } \\
\cline { 2 - 10 } & $\mathbf{2 0 0 9}$ & $\mathbf{2 0 1 2}$ & $\mathbf{2 0 1 5}$ & $\mathbf{2 0 1 7}$ & $\mathbf{2 0 0 9}$ & $\mathbf{2 0 1 2}$ & $\mathbf{2 0 1 5}$ & $\mathbf{2 0 1 7}$ \\
\hline 00-Live animals & 7.52 & 3.59 & 2.42 & 2.92 & 0.04 & 0.12 & 0.06 & 0.11 \\
\hline 01- Meat and preparations & 2.78 & 1.35 & 1.29 & 1.17 & 0.46 & 0.43 & 0.84 & 0.31 \\
\hline 02- Dairy products \& eggs & 5.78 & 2.45 & 2.43 & 1.77 & 0.94 & 0.89 & 0.59 & 0.63 \\
\hline 03- Fish and preparations & 0.14 & 0.07 & 0.10 & 0.28 & 0.74 & 0.50 & 0.42 & 0.64 \\
\hline 04- Cereals \& preparations & 16.21 & 16.51 & 9.68 & 8.88 & 0.33 & 0.27 & 0.41 & 0.57 \\
\hline 05- Vegetables \& fruit & 3.59 & 3.12 & 3.34 & 3.47 & 0.89 & 0.74 & 1.34 & 0.95 \\
\hline 06- Sugars \& honey & 9.06 & 6.80 & 4.46 & 3.79 & 0.76 & 1.28 & 0.64 & 0.54 \\
\hline 07- Coffee, tea, cocoa & 1.13 & 0.61 & 0.52 & 0.59 & 0.26 & 0.24 & 0.25 & 0.21 \\
\hline 08-Feeding stuff for anim. & 3.06 & 3.67 & 2.21 & 2.65 & 0.15 & 0.19 & 0.22 & 0.20 \\
\hline 09-Miscell. edible products & 1.99 & 1.31 & 1.12 & 1.46 & 0.19 & 0.16 & 0.16 & 0.13 \\
\hline 11-Beverages & 5.93 & 4.36 & 2.86 & 2.82 & 0.22 & 0.23 & 0.21 & 0.31 \\
\hline 12-Tobbaco\&manufactures & 2.00 & 1.21 & 2.54 & 1.90 & 0.30 & 0.27 & 0.30 & 0.34 \\
\hline 21-Hides, skins, furskins & 3.61 & 1.85 & 1.89 & 5.25 & 3.72 & 2.12 & 2.71 & 10.71 \\
\hline 22-Oil-seeds \& ol. fruits & 0.93 & 1.27 & 1.87 & 1.90 & 0.05 & 0.06 & 0.04 & 0.22 \\
\hline 29-Crude an. \& veg. mat. & 1.42 & 1.15 & 0.82 & 0.92 & 0.30 & 0.53 & 0.60 & 0.26 \\
\hline 41-Animal oils \& fats & 0.80 & 0.76 & 0.59 & 0.89 & 0.00 & 0.01 & 0.00 & 0.00 \\
\hline 42-Fixed veg. fats \& oils & 6.32 & 7.70 & 4.71 & 4.74 & 1.25 & 1.08 & 1.68 & 1.49 \\
\hline $\begin{array}{l}\text { 43-Anim. or veg. fats \& oils, } \\
\text { pr. }\end{array}$ & 1.91 & 3.37 & 1.64 & 2.60 & 0.16 & 0.18 & 0.16 & 0.10 \\
\hline
\end{tabular}

Source: Authors' calculations based on UNCTADStat

Comparative advantages in relation to other sectors in national economy $\left(\mathrm{RCA}_{3}\right)$ in all analyzed years in Montenegro are recorded only for division 11-Beverages (Table 6).

Table 6. The revealed comparative advantage indexes- $\mathrm{RCA}_{3}$ of individual SITC sections of agrarian sector of North Macedonia and Montenegro on global market

\begin{tabular}{|l|r|r|r|r|r|r|r|r|}
\hline & \multicolumn{4}{|c|}{ North Macedonia } & \multicolumn{4}{c|}{ Montenegro } \\
\cline { 2 - 10 } & $\mathbf{2 0 0 9}$ & $\mathbf{2 0 1 2}$ & $\mathbf{2 0 1 5}$ & $\mathbf{2 0 1 7}$ & $\mathbf{2 0 0 9}$ & $\mathbf{2 0 1 2}$ & $\mathbf{2 0 1 5}$ & $\mathbf{2 0 1 7}$ \\
\hline 00-Live animals & 6.79 & 1.76 & 1.34 & 1.01 & 0.00 & 0.00 & 0.01 & 0.02 \\
\hline 01- Meat and preparations & 0.48 & 0.40 & 0.27 & 0.22 & 0.43 & 0.41 & 0.63 & 0.67 \\
\hline 02- Dairy products \& eggs & 0.29 & 0.33 & 0.40 & 0.37 & 0.00 & 0.02 & 0.04 & 0.04 \\
\hline 03- Fish and preparations & 0.77 & 0.54 & 0.11 & 0.16 & 0.70 & 0.01 & 0.00 & 0.03 \\
\hline 04- Cereals \& preparations & 0.99 & 0.82 & 1.07 & 1.13 & 0.30 & 0.50 & 0.51 & 0.65 \\
\hline 05- Vegetables \& fruit & 3.81 & 3.65 & 2.99 & 2.25 & 1.10 & 0.99 & 0.72 & 0.51 \\
\hline
\end{tabular}




\begin{tabular}{|l|r|r|r|r|r|r|r|r|}
\hline & \multicolumn{4}{|c|}{ North Macedonia } & \multicolumn{4}{c|}{ Montenegro } \\
\cline { 2 - 10 } & $\mathbf{2 0 0 9}$ & $\mathbf{2 0 1 2}$ & $\mathbf{2 0 1 5}$ & $\mathbf{2 0 1 7}$ & $\mathbf{2 0 0 9}$ & $\mathbf{2 0 1 2}$ & $\mathbf{2 0 1 5}$ & $\mathbf{2 0 1 7}$ \\
\hline 06- Sugars \& honey & 0.41 & 0.28 & 0.32 & 0.25 & 0.19 & 0.01 & 0.03 & 0.05 \\
\hline 07- Coffee, tea, cocoa & 0.34 & 0.28 & 0.27 & 0.27 & 0.03 & 0.54 & 0.70 & 0.41 \\
\hline 08-Feeding stuff for anim. & 0.06 & 0.07 & 0.06 & 0.06 & 0.22 & 0.01 & 0.06 & 0.14 \\
\hline 09-Miscell. edible products & 0.48 & 0.39 & 0.39 & 0.36 & 0.36 & 0.63 & 0.05 & 0.08 \\
\hline 11-Beverages & 4.82 & 3.99 & 2.16 & 2.14 & 2.71 & 2.17 & 2.26 & 1.90 \\
\hline 12-Tobbaco\&manufactures & 11.37 & 6.46 & 4.91 & 5.12 & 0.20 & 0.96 & 2.70 & 0.33 \\
\hline 21-Hides, skins, furskins & 3.12 & 4.41 & 4.17 & 2.69 & 329.41 & 15.59 & nv & 487.79 \\
\hline 22-Oil-seeds \& ol. fruits & 0.20 & 0.49 & 0.20 & 0.33 & 0.15 & 0.00 & 0.02 & 0.00 \\
\hline 29-Crude an. \& veg. mat. & 0.56 & 0.68 & 0.85 & 1.35 & 0.29 & 0.25 & 0.17 & 0.20 \\
\hline 41-Animal oils \& fats & 0.04 & 0.01 & 0.01 & 0.01 & 0.72 & 4.07 & 4.13 & 3.36 \\
\hline 42-Fixed veg. fats \& oils & 0.37 & 0.33 & 0.53 & 0.18 & 0.04 & 0.74 & 0.08 & 0.06 \\
\hline $\begin{array}{l}\text { 43-Anim. or veg. fats \& oils, } \\
\text { pr. }\end{array}$ & 0.20 & 0.39 & 0.38 & 0.49 & 1.37 & 6.52 & 0.59 & 1.29 \\
\hline
\end{tabular}

Source: Authors' calculations based on UNCTADStat

Notes: nv-import of this product is not recorded in a given year

In some years this also applies to divisions: 05-Vegetables and fruit; 12-Tobacco and manufactures; 41-Animal oil and fats and 43-Animal or vegetable fats and oil, processed. Division 21 has very high values of $\mathrm{RCA}_{3}$ index, which is result of extremely high export, much higher than import (for example, exports were 54 times higher than imports in 2015), and small import values.

\section{Conclusions}

The foreign trade of Serbia and selected countries in the region (Bosnia and Herzegovina, Montenegro and North Macedonia) is characterized by a large deficit, which indicates a relatively low level of competitiveness. The growing openness of economies of these countries is more the result of rising import dependence than the tendency of exports. Import ratio reaches around 45\% in Serbia and in Bosnia and Herzegovina and in Montenegro about 53\%, while it is the highest in Macedonia (70\%). The foreign trade coverage ratio in Serbia has increased in the observed period and is highest comparing to other selected countries. Unsatisfactory competitiveness of economies of Serbia and neighbouring countries is confirmed by index of revealed comparative advantage $\left(\mathrm{RCA}_{2}\right)$.

Agro-food products are traditionally significant for the overall economic development of the Republic of Serbia. The positive foreign trade balance in the exchange of agrarian products among Western Balkan countries has only Serbia, where foreign trade coverage ratio of agro-food products exceeds $100 \%$, which points to the competitiveness of agrarian sector and separates it from other sectors of the economy. The share of agrarian sector in total exports is the highest in Serbia, around 20\%, which can be justified in available resources for the development of agriculture and slow development of other activities. Those findings confirm the hypothesis that the agrarian sector of Serbia is of greater importance for levelling the trade balance in comparison with the selected countries in the region. 
The revealed comparative advantages on global market in the export of agrarian products of Serbia, or the $\mathrm{RCA}_{1}$ index values greater than one in all years of the analysis, have ten divisions whose contribution to exports is also the highest. The highest comparative advantages in the first analyzed year had division 06-Sugars, sugar preparations and honey, while in the following years more competitive commodities are cereals; vegetables and fruits; and in the last years division 12-Tobacco and tobacco manufactures.

Divisions that have the lowest values of $\mathrm{RCA}_{1}$ index in Serbia, indicating that they are uncompetitive on global market are: 01-Meat and meat preparations and 03-Fish, crustaceans and molluscs.

The countries included in the analysis are characterized by a lower level of competitiveness of agrarian sector and smaller number of products that have comparative advantages in the exchange on global market, which confirms the second starting hypothesis. In $\mathrm{BiH}$ there are five divisions (among which the most important are 02-Dairy products and birds' eggs and 06-Sugars, sugar preparations and honey). In Macedonia, also five commodity divisions have comparative advantages in the exchange on global market (and the most significant are: 04-Cereals and cereal preparations; 05-Vegetables and fruit; 11-Beverages; 12-Tobacco and tobacco manufactures). Montenegro achieves the revealed comparative advantages in the exchange of four divisions: 01-Meat and meat preparations; 05-Vegetables and fruit; 11-Beverages and 41-Animal oil and fats. Among all the countries included in the analysis, only Montenegro achieves competitive advantages in the exchange of animal oils and fats, while all observed countries have comparative advantages on global market in trade of vegetables and fruits. The $\mathrm{RCA}_{3}$ index confirm that almost all divisions of agro-food products in Serbia have greater comparative advantages compared to other sectors of the national economy, while in selected countries in the region fewer divisions show such competitive advantages.

\section{Acknowledgements}

This paper is a part of the research on the project Serbian Rural Labour Market and Rural Economy - Revenue Diversification and Poverty Mitigation, No. ON 179028 financed by the Ministry of Education, Science and Technological Development of the Republic of Serbia.

\section{Conflict of interests}

The authors declare no conflict of interest.

\section{References}

1. Ali, Q., Shaikh, M., Shah, A. B. \& Shaikh, F. M. (2017). Relationship between Export and Economic Growth in Pakistan by Using OIS Technique. International Journal of Case Studies, 6(4), 27-33. 
2. Baldwin, R. E. (2003). Openness and Growth: What's the Empirical Relationship? NBER Working Paper No 9578, National bureau of economic research, Cambridge.

3. Balassa, B. (1965). Trade Liberalisation and "Revealed Comparative Advantage". The Manchester School of Economic and Social Studies, 33, 99-123.

4. Balassa, B. (1985). Exports, policy choices, and economic growth in developing countries after the 1973 oil shock. Journal of Development Economics, 18(1), 23 35.

5. Bojnec, Š. (2001). Trade and Revealed Comparative Advantage Measures (Regional and Central and East European Agricultural Trade). Eastern European Economics, 39(1), 72-98.

6. Bojnec, Š. \& Fertö, I. (2007). Comparative Advantages in Agro-Food Trade of Hungary, Croatia and Slovenia with the European Union. .Discussion Paper No. 106, IAMO, Halle, Germany.

7. Boljanović, S. (2013). A comparative analysis of the impact of foreign direct investments on the structure and specialization of Serbian and Hungarian export. Ekonomske teme, 51(1), 37-57. [in Serbian: Бољановић, С. (2013), Компаративна анализа утицаја страних директних инвестиција на структуру и специјализацију српског и мађарског извоза].

8. Božić, D. \& Nikolić, M. (2013-a). Significance and Comparative Advantages of the Agrarian Sector in Serbian Foreign Trade. 50 th Anniversary of Department of Agricultural Economics - Thematic Proceedings Agriculture and Rural Development - Challenges of Transition and Integration Processes, Faculty of Agriculture, University of Belgrade, 13-31.

9. Božić, D. \& Nikolić, M. (2013-b). Regional Analysis of Agricultural and Food Trade of Serbia. 135 EAAE Seminar Challenges for the Global Agricultural Trade Regime after Doha, Belgrade, 83-98.

10. Božić, D. \& Nikolić, M. (2016). Characteristics of Serbian Foreign Trade of Agricultural and Food Products. Marketing, 47(4), 293-304. [in Serbian: Божић, Д. \& Николић, M. (2016), Обележја спољнотрговинске размене пољопривреднопрехрамбених производа Србије].

11. Božić, D. \& Nikolić, M. (2017). Serbian foreign trade and importance of agrarian sector. Teme, 41(3), 711-731. [in Serbian: Божић, Д. \& Николић, М. (2017), Спољнотрговинска размена Србије и значај аграрног сектора].

12. Fertö, I. \& Hubbard, J. L. (2002). Revealed Comparative Advantage and Competitiveness in Hungarian Agri-Food Sectors. Discussion Papers, 2002/8, Institute of Economics Hungarian Academy of Sciences, Budapest.

13. Freebairn, J. (1986). Implications of Wages and Industrial Policies on Competitiveness of Agricultural Export Industries. Review of Marketing and Agricultural Economics, 55(1), 79-87. 
14. Frohberg, K., Hartmann, M. (1997): Comparing Measures of Competitiveness, Discussion Paper No. 2, Institute of Agricultural Development in Central and Eastern Europe (IAMO), Halle/Saale.

15. Gözgör, G. \& Can, M. (2017). Causal Linkages among the Product Diversification of Exports, Economic Globalization and Economic Growth. Review of Development Economics, 21(3), 888-908.

16. Haddad, M. E., Lim, J. J. \& Saborowski, C. (2011). Trade Openness Reduces Growth Volatility When Countries are Well Diversified. Policy Research Working Papers 5222, World Bank, Washington.

17. Jaćimović, D., Bjelić, P. \& Marković, I. (2013). The impact of the world economic crisis on foreign investments and trade flows in the Western Balkans. Ekonomske teme, 51(1), 1-20. [in Serbian: Јаћимовић, Д., Бјелић, П. \& Марковић, И. (2013), Утицај светске економске кризе на међународне инвестиционе и трговинске токове у региону Западног Балкана].

18. Jefferson Institute (2003). Competitives of Serbian economy. Belgrade. [in Serbian: Jefferson Institute (2003), Конкурентност привреде Србије].

19. Liesner, H. H. (1958). The European Common market and British industry. Economic Journal, 68(270), 302-316.

20. López, Sanjuán A. \& Dawson, P. J. (2010). Agricultural Exports and Economic Growth in Developing Countries: A Panel Cointegration Approach. Journal of Agricultural Economics, 61(3), 565-583.

21. Porter, M. E. (1990). The Competitive Advantage of Nations, London: Macmillian.

22. Sayef, B. (2017). The Long Run and Short Run Impacts of Exports on Economic Growth: Evidence from Gabon. Economic Research Guardian, 7(1), 40-57.

23. Šegota, A., Tomljanović, M. \& Huđek, I. (2017). Contemporary approaches to measuring competitiveness - the case of EU member states. Zbornik radova Ekonomskog fakulteta u Rijeci, 35(1), 123-150.

24. Tešić, J. (2013). Openness to trade and competitiveness of small transitional economies. Acta Economica, 11(18), 317-336. [in Serbian: Тешић, J. (2013), Отвореност и конкурентност малих транзиционих привреда].

25. United Nations Conference for Trade and Development, UNCTAD's Trade Analysis and Information System - TRAINS Database http://unctadstat.unctad.org

26. Utkulu, U. \& Seymen, D. (2004). Revealed Comparative Advantage and Competitiveness: Evidence for Turkey vis-avis the EU 15. The European Trade Study Group-ETSG $6^{\text {th }}$ Annual Conference, Nottingham.

27. Vollrath, T. L. (1991). A Theoretical Evaluation of Alternative Trade Intensity Measures of Revealed Comparative Advantage. Weltwirt-schaftliches Archiv, 127, 265-280.

28. World Economic Forum (2018). Global Competitiveness Report 2018, Geneva. 